\title{
Tidal and seasonal carbon and nutrient dynamics of the Guadalquivir estuary and the Bay of Cádiz (SW Iberian Peninsula)
}

\author{
M. Ribas-Ribas ${ }^{1, *}$, E. Anfuso ${ }^{1}$, A. Gómez-Parra ${ }^{1}$, and J. M. Forja ${ }^{1}$ \\ ${ }^{1}$ Departamento de Química-Física. Facultad de Ciencias del Mar y Ambientales, Universidad de Cádiz, Campus Río San \\ Pedro, s/n, Puerto Real, Cádiz, 11510, Spain \\ *now at: School of Ocean and Earth Science, National Oceanography Centre, Southampton, University of Southampton, \\ Waterfront Campus, European Way, Southampton SO14 3ZH, UK
}

Correspondence to: M. Ribas-Ribas (m.ribas-ribas@soton.ac.uk)

Received: 14 September 2012 - Published in Biogeosciences Discuss.: 19 October 2012

Revised: 12 May 2013 - Accepted: 3 June 2013 - Published: 4 July 2013

\begin{abstract}
To study the effects of the physical environment on carbon and nutrient cycle dynamics on the north-eastern shelf of the Gulf of Cádiz, changes in currents, tides, salinity, temperature, carbon system parameters (fugacity of $\mathrm{CO}_{2}$ $\left(f \mathrm{CO}_{2}\right)$, dissolved organic carbon, dissolved inorganic carbon (DIC) and $\mathrm{pH}$ ) and other related parameters(dissolved oxygen, total dissolved nitrogen (TDN), nutrients and suspended particulate matter) were measured in transects across the Guadalquivir estuary and Bay of Cádiz mouths. The main objective of this study is to investigate the influence of these inner ecosystems on the carbon and nutrient distributions on the adjacent continental shelf. Three cruises were undertaken in June 2006, November 2006 and February 2007. During the whole study period, Guadalquivir estuary exported components at a rate of $3 \mathrm{Gmol}$ of $\mathrm{SiO}_{2}, 4 \mathrm{Gmol}$ of DIN, $3 \mathrm{Gmol}$ of TDN, $31 \mathrm{Gmol}$ of DOC and $604 \mathrm{Gmol}$ of DIC per year. On the other hand, Bay of Cádiz imported $3 \mathrm{Gmol}$ of $\mathrm{SiO}_{2}, 1 \mathrm{Gmol}$ of DIN, $2 \mathrm{Gmol}$ of TDN, $33 \mathrm{Gmol}$ of DOC and $562 \mathrm{Gmol}$ of DIC per year. Diurnal variability of $f \mathrm{CO}_{2}$ could have a potentially important implication on the estimate of air-sea $\mathrm{CO}_{2}$ fluxes. Tides influence velocity and transport of carbon and nutrients: we found statistically significant differences ( $p<0.0001, n=220$ ) between the flood tide (the mean velocity was $4.85 \mathrm{~cm} \mathrm{~s}^{-1}$ ) and the ebb tide (the mean velocity was $-5.67 \mathrm{~cm} \mathrm{~s}^{-1}$ ). Biological activity and diurnal changes have also an important role on the carbon and nutrient dynamics. Seasonal carbon and nutrient variations were found. During June, both systems were exporting components to the adjacent continental shelf of the Gulf of Cádiz, whereas in February both systems were im-
\end{abstract}

porting. Monthly studies should be undertaken to completely understand this dynamic system.

\section{Introduction}

Coastal and marginal seas play a key role in the global carbon cycle by linking terrestrial, oceanic, and atmospheric reservoirs (Walsh, 1991). Where, when, and how organic carbon is decomposed into carbon dioxide and lost to the atmosphere through the coastal continuum of rivers, estuaries, marshes, and continental shelves before reaching the slope and the open ocean is still controversial (Cai, 2011). Furthermore, the importance of quantifying the transport of nutritive substances to the coastal zone has been highlighted by the International Geosphere-Biosphere Programme-LandOcean Interactions in the Coastal Zone (IGBP-LOICZ) (Gordon et al., 1996).

Previous studies have pointed out the importance of the inner ecosystems into the north-eastern shelf of the Gulf of Cádiz (Ribas-Ribas et al., 2011a, b, c; de la Paz et al., 2007; Navarro and Ruiz, 2006). Ribas-Ribas et al. (2011a) found out that the Guadalquivir River is a significant source of inorganic carbon to the adjacent zone of the Atlantic Ocean. Ribas-Ribas et al. (2011b) found a strong negative correlation between salinity and $f \mathrm{CO}_{2}$. Ribas-Ribas et al. (2011c) found also a strong inverse linear correlation between salinity and total dissolved nitrogen (TDN) and suggested that the Guadalquivir River was a major source of dissolved organic matter for offshore sites in the surface waters 
Table 1. Transects in the Bay of Cádiz (BC) and the Guadalquivir estuary (GL), date when transects were done and hours of the tidal cycle covered. In some cases $(*)$, due to bad weather conditions, the $24 \mathrm{~h}$ cycle could not be completed.

\begin{tabular}{llr}
\hline Transect & Date & Hours \\
\hline 1BC & $21-22 / 06 / 06$ & 24 \\
1GL & $28-29 / 06 / 06$ & 24 \\
2BC & $23-24 / 11 / 06$ & $16^{*}$ \\
2GL & $29-30 / 11 / 06$ & 24 \\
3BC & $04-05 / 02 / 07$ & 24 \\
3GL & $07 / 02 / 07$ & $10^{*}$ \\
\hline
\end{tabular}

of the north-eastern shelf of the Gulf of Cádiz. A number of studies have focused on estuary and bay transport but mainly along the river course and anchor station (Borges and Frankignoulle, 2002; Dale and Prego, 2003; Goñi et al., 2009). Carbon/nitrogen cycle parameters show a big seasonal variability on the north-eastern shelf of the Gulf of Cádiz (Navarro and Ruiz, 2006; Ribas-Ribas et al., 2011a, b, c; Ribas-Ribas et al., 2013).

Thus, these studies emphasized the importance to better know the transport from/to the Guadalquivir estuary and the Bay of Cádiz. To this end, we present high-frequency fugacity of $\mathrm{CO}_{2}\left(f \mathrm{CO}_{2}\right)$, dissolved oxygen, dissolved organic carbon, total dissolved nitrogen, dissolved inorganic carbon (DIC), $\mathrm{pH}$, nutrients, suspended particulate material and ancillary data recorded for three cruises off the Guadalquivir estuary and the Bay of Cádiz. We firstly discuss the diurnal and tidal carbon and nutrient dynamics in both systems. We then discuss seasonal fate and fluxes of carbon and nutrient from the Guadalquivir estuary and the Bay of Cádiz on the continental shelf of the Gulf of Cádiz. This study provides insight into the fluxes along a perpendicular axis of the mouth of the inner ecosystems.

\section{Material and methods}

\subsection{Study area and field sampling}

The study was carried out over the north-eastern shelf of the Gulf of Cádiz, which is located on the south-western coast of the Iberian Peninsula (Fig. 1). The basin receives significant fluvial inputs associated with the discharge of large rivers such as the Guadiana, Guadalquivir, Guadalete and Tinto-Odiel. The Guadalquivir River is the main fluvial source draining into the Gulf of Cádiz margin. Coastal waters near the mouth of the Guadalquivir River and in the Bay of Cádiz present the highest primary production within the Gulf of Cádiz (Navarro and Ruiz, 2006). The primary production in this area has been reported to vary between $4.5 \mathrm{~g} \mathrm{C} \mathrm{m}^{-2} \mathrm{~d}^{-1}$ in spring and $2.0 \mathrm{~g} \mathrm{C} \mathrm{m}^{-2} \mathrm{~d}^{-1}$ in summer (Huertas et al., 2006). The coastal fringe of the Gulf of

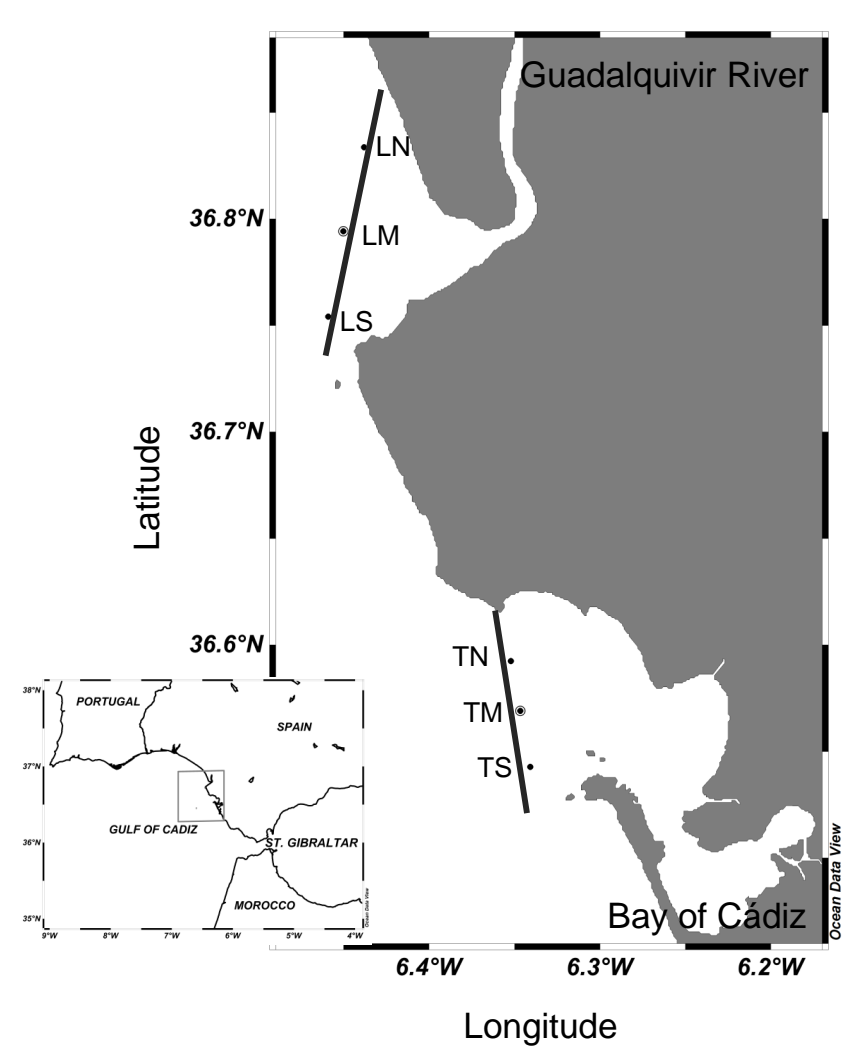

Fig. 1. Map of the north-eastern shelf of the Gulf of Cádiz showing the location of sampled stations (solid points). Lines represent transects where currents and physicochemical variables were measured.

Cádiz is also characterized by the presence of waters warmer and colder than those detected in the rest of the basin during early summer and winter, respectively (Vargas et al., 2003; Navarro and Ruiz, 2006), and by a strong meteorological forcing caused by quasi-permanent episodes of winds (Ribas-Ribas et al., 2011b).

The data reported in this work were collected during 3 cruises that took place 21/22 and 28/29 June 2006, 23/24 and 29/30 November 2006 and 4/5 and 7 February 2007 on board of the R/V Mytilus. Unfortunately, due to logistical reasons, no cruise has been undertaken during spring. Surveys consisted of repeated transects in along-shore direction, covering the mouth of Guadalquivir estuary and the Bay of Cádiz (Fig. 1; Table 1). The chosen transect off Guadalquivir estuary was $9 \mathrm{~km}$, and water depth varied from 5 to $12 \mathrm{~m}$. The chosen transect off Bay of Cádiz was $6 \mathrm{~km}$, and water depth varied from 14 to $18 \mathrm{~m}$. Each transect took about $2 \mathrm{~h}$ round trip. Surveys were carried out continuously for $24 \mathrm{~h}$ (as long as weather conditions permitted). We continuously registered currents with acoustic Doppler current profiler (ADCP), temperature, salinity and fugacity of $\mathrm{CO}_{2}\left(f \mathrm{CO}_{2}\right)$. In addition, in every forward transect we stopped in three stations to collect discrete samples. At each station, near-surface $(\sim 3 \mathrm{~m}$ below the sea surface) water samples were collected with 
Niskin bottles. Additional water samples were collected at near-bottom ( $\sim 5 \mathrm{~m}$ above the seafloor $)$ at the deepest station (south of the Bay of Cádiz and the middle of the Guadalquivir estuary) (Fig. 1). Salinity, temperature and $f \mathrm{CO}_{2}$ were sampled with a frequency of $30 \mathrm{~s}$ from the surface seawater supply of the ship (pump inlet at a depth of $3 \mathrm{~m}$ ). To match the dataset of continuous and discrete samples, continuous data were averaged during the time the ship stopped for stations.

\subsection{Physical parameters}

Salinity and temperature were measured using a SeaBird thermosalinograph (Micro-SeaBird 45), before water entry into the gas equilibrator. Salinity and temperature are estimated to be accurate to \pm 0.005 and $\pm 0.004^{\circ} \mathrm{C}$, respectively, according to the SeaBird calibration data. Velocity measurements between $4 \mathrm{~m}$ and bottom were obtained along the route by the R/V Mytilus's RD broadband instrument at $300 \mathrm{kHz}$. Raw data were post-processed by CASCADE 6.1 software (Lebot et al., 2011), which includes ship velocity removal, quality flag assignment and data filtering. Orthogonal velocities to the sections were estimated and punctual data extracted at those locations where chemical samples were acquired.

The instantaneous flux across the section of one constituent is computed with velocity and concentrations taken every $2 \mathrm{~h}$ and is defined as

$F_{c}=c \cdot u$,

where $c$ represents the constituent concentration, and $u$ is the punctual current velocity. A similar approach has also been used by Goñi et al. (2009).

The sections have been calculated for every sampling taking into account the bathymetry and the tide height. It could be integrated for the day to have the diurnal flux. Then, we extrapolated first to the seasonal flux and then to the annual flux, taking into account the associated uncertainties. Estimating the transport uncertainties is important, since it conditions the influence of the velocity data on the final results. The uncertainties have two sources: one is due to the instrumental error, and the other is due to the physical environment (e.g. fine-scale currents, for instance, whose scaling is assumed to be smaller than a few kilometres). The between-station route is divided into $N$ independent $x$-metre segments. The velocity standard deviations (std's) are calculated between 2 depths for all the segments, representing the contributions of the two uncertainty sources. The velocity uncertainty is then deduced from the vertical and horizontal averages of the std values divided by $N$. Uncertainties are found between 0.01 and $0.06 \mathrm{~m} \mathrm{~s}^{-1}$ for the whole section. The concentration variables have also an associated vertical and horizontal uncertainty.

\subsection{Chemical parameters}

At each station samples were collected to analyse total alkalinity (TA) and $\mathrm{pH}$. Analyses of the filtered samples were carried out on board. The $\mathrm{pH}$ was measured with a glass combined electrode (Metrohm) calibrated using the buffer Tris/Tris- $\mathrm{HCl}$ (ionic strength $0.7 \mathrm{M}$ ) on the total $\mathrm{pH}$ scale with an accuracy of \pm 0.003 . TA was measured in $100 \mathrm{~mL}$ samples using an automatic potentiometric titrator "Metrohm 794 analyzer", with a combination glass electrode, calibrated following the protocol described by DelValls and Dickson (1998). TA computation was made applying the Gran function to the titration curve. The TA measurements were validated with reference standards obtained from A. Dickson (Scripps Institute of Oceanography, San Diego, USA) to an accuracy of $\pm 2 \mu \mathrm{mol} \mathrm{kg} \mathrm{kg}^{-1}$. Dissolved inorganic carbon was calculated from $\mathrm{pH}$ and $\mathrm{TA}$ using thermodynamic equations in seawater and the constants described by Mehrbach et al. (1973) refitted by Dickson and Millero (1987) for carbonate and by Dickson (1990) for sulfate. The calculated error for DIC was $\pm 2.6 \mu \mathrm{mol} \mathrm{kg}{ }^{-1}$ using error propagation of variances in the carbonate system (Dickson and Riley, 1978). The surface water $\mathrm{CO}_{2}$ molar fraction $\left(x \mathrm{CO}_{2}\right)$ was measured with a non-dispersive infrared gas analyser (Licor ${ }^{\circledR}$, LI-6262). At the beginning and the end of each day, the equipment was calibrated with two standards: $\mathrm{CO}_{2}$ free-air and a high $\mathrm{CO}_{2}$ standard gas with a concentration of $530 \mathrm{ppm}$ (with pre-deployment laboratory calibration against Air Liquide France standard). The temperature inside the equilibrator was measured continuously by means of a platinum resistance thermometer (PT 100 probe). The temperature difference between the ship's sea inlet and the equilibration system was less than $0.8^{\circ} \mathrm{C}$ during all the cruises. The accuracy (precision) of seawater $f \mathrm{CO}_{2}$ measurement was $\pm 3( \pm 0.5) \mu \mathrm{atm}$. The water-saturated $f \mathrm{CO}_{2}$ in the equilibrator was calculated from the $x \mathrm{CO}_{2}$ in dry air; the atmospheric pressure data was provided by the Spanish national government (Organismo Público Puertos del Estado); and equilibrium water vapour was calculated according to the protocol described in Dickson et al. (2007). The formulation proposed by Takahashi et al. (1993) was employed for the partial pressure corrections to in situ water temperature. The atmospheric $f \mathrm{CO}_{2}$ data were obtained from the monthly data at Terceira Island station (Azores, Portugal), taken from National Oceanic and Atmospheric Administration (NOAA/CMDL/CCGG air sampling network) data available online at http://www.esrl.noaa.gov/gmd/dv/ data/?site=azr. It should be pointed out that this station is quite far away from our study site and that its location is considered an open ocean site. However, the study sites are coastal and likely influenced by anthropogenic sources of $\mathrm{CO}_{2}$ (dependent upon the wind direction). This assumption could affect the estimates $\mathrm{CO}_{2}$ flux by overestimating the flux we reported. 

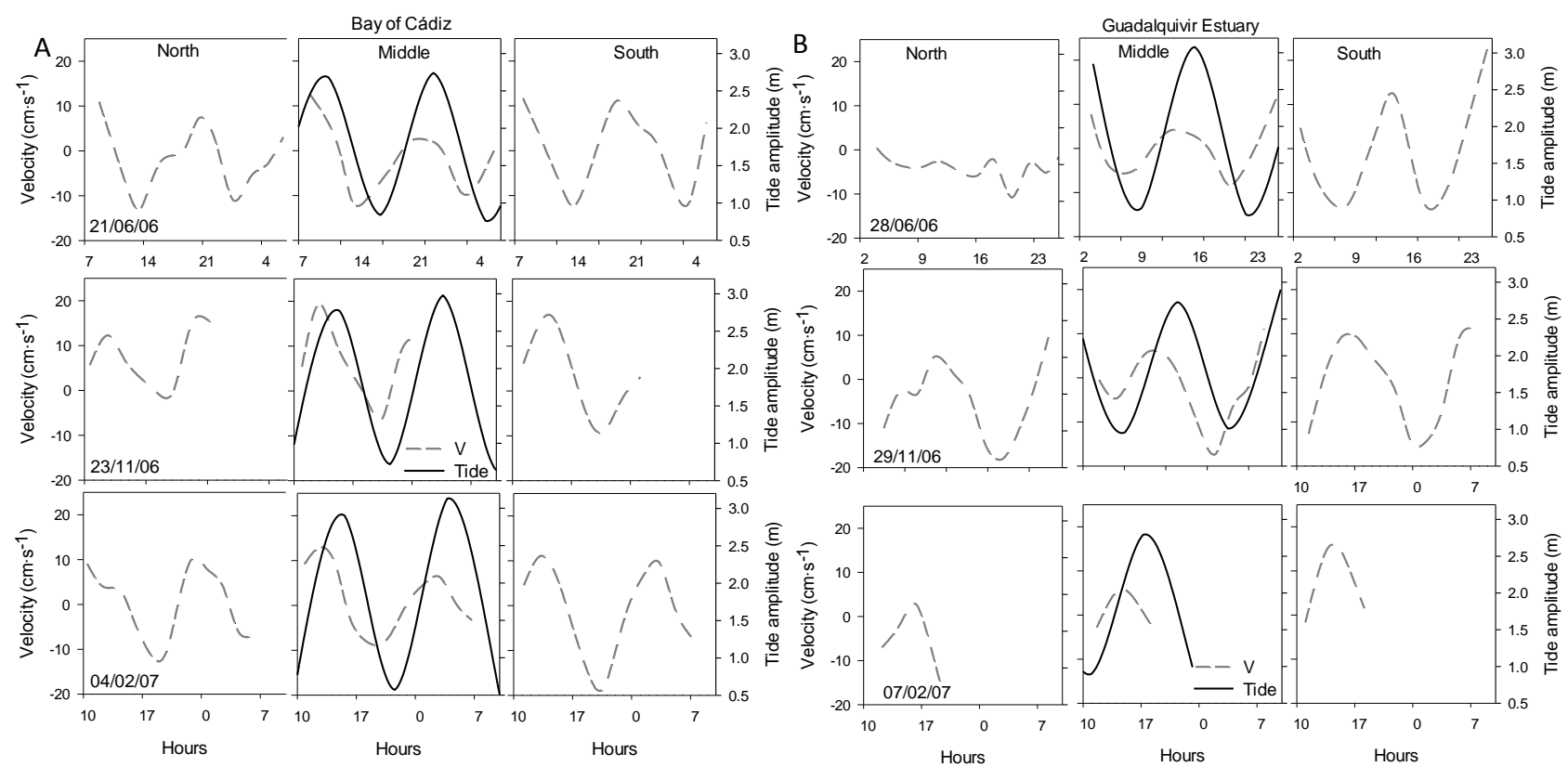

Fig. 2. Tidal cycles of surface velocity (grey dashed line) and one tide amplitude (black solid line) from the transect off the Bay of Cádiz (A) and Guadalquivir estuary (B) at the three different stations (Fig. 1). Autumn cycle in the Bay of Cádiz and winter cycle in the Guadalquivir estuary were not closed due to bad weather conditions.

Samples for DOC and TDN were collected in $10 \mathrm{~mL}$ pre-combusted ampoules and were filtered through precombusted Whatman GF/F filters of $47 \mathrm{~mm}$ diameter $(0.7 \mu \mathrm{m}$ nominal pore size). Samples were taken in duplicate, acidified by addition of $85 \% \mathrm{H}_{3} \mathrm{PO}_{4}(\mathrm{pH}<2)$, sealed and stored in the dark at $4{ }^{\circ} \mathrm{C}$ in the laboratory. The Shimadzu instrument used in this study was the commercially available Model TOC-5000 analyser with quartz combustion column in the vertical position filled with $1.2 \%$ Pt silica pillow. In addition, system performance was verified daily using standards produced by the Hansell Certified Reference Material (CRM) programme. Three seawater CRM and three low carbon water (LCW) analyses were performed each analytical day. The nominal values provided by the Hansell Laboratory were $41-44 \mu \mathrm{M}$ and $33 \mu \mathrm{M}$ for DOC and total dissolved nitrogen (TDN), respectively. The measured values were $42.5 \pm 0.9 \mu \mathrm{M}$ and $32.8 \pm 0.3 \mu \mathrm{M}$. LCW values measured were $1.9 \pm 1.3 \mu \mathrm{M}$ (nominal $1-2 \mu \mathrm{M}$ ) and $0.3 \pm 0.1 \mu \mathrm{M}$ (nominal $0 \mu \mathrm{M}$ ) for DOC and TDN, respectively.

Dissolved oxygen samples were fixed in oceanographic Winkler bottles and stored in darkness for $24 \mathrm{~h}$, as described by Grasshoff et al. (1983), for later analysis by potentiometric titration (Metrohm 670 Titroprocessor).

For the assessment of the suspended particulate matter (SPM) and the particulate organic carbon (POC), $500 \mathrm{~mL}$ samples were filtered on board onto precombusted Whatman $\mathrm{GF} / \mathrm{F}$ filters of $47 \mathrm{~mm}$ diameter $(0.7 \mu \mathrm{m}$ nominal pore size $)$ and Whatman GF/F filter of $25 \mathrm{~mm}$ diameter $(0.7 \mu \mathrm{m}$ nominal pore size), respectively, and were immediately frozen at
$-20{ }^{\circ} \mathrm{C}$. Once at the laboratory, they were dried out in an oven and weighted to calculate total SPM. Filters were completely rinsed of residual salt prior to drying. Subsequently, they were ashed at $450{ }^{\circ} \mathrm{C}$ in a muffle furnace for $4 \mathrm{~h}$ and once again weighted to calculate the inorganic particulates (Loring and Rantala, 1992).

Samples for nutrients (nitrate, silicate and nitrite) were filtered on board through $0.45 \mu \mathrm{m}$ Millipore filters, immediately frozen at $-20^{\circ} \mathrm{C}$, and analysed in the laboratory. Nutrients were determined by segmented flow analysis with Alpkem autoanalysers, following Grasshoff et al. (1983).

Seasonal and spatial differences (between the Guadalquivir estuary and the Bay of Cádiz) in hydrological and biogeochemical characteristics were analysed using a non-parametric analysis of variance (Kruskal-Wallis test) as the data did not follow a normal distribution.

\section{Results and discussion}

\subsection{Small-scale influence on carbon and nutrient dynamics: tidal and diurnal influences}

The general trend of surface velocity varied with tidal influence (Fig. 2). Positive velocity values indicate onshore, while negative values represent offshore flux. We group the stations between ebb and flood tide as follows: ebb tide data were measured $2 \mathrm{~h}$ before and after the low tide and the rest of the data for the flood tide. We found statistically significant differences ( $p<0.0001, n=220)$ : during the flood tide 

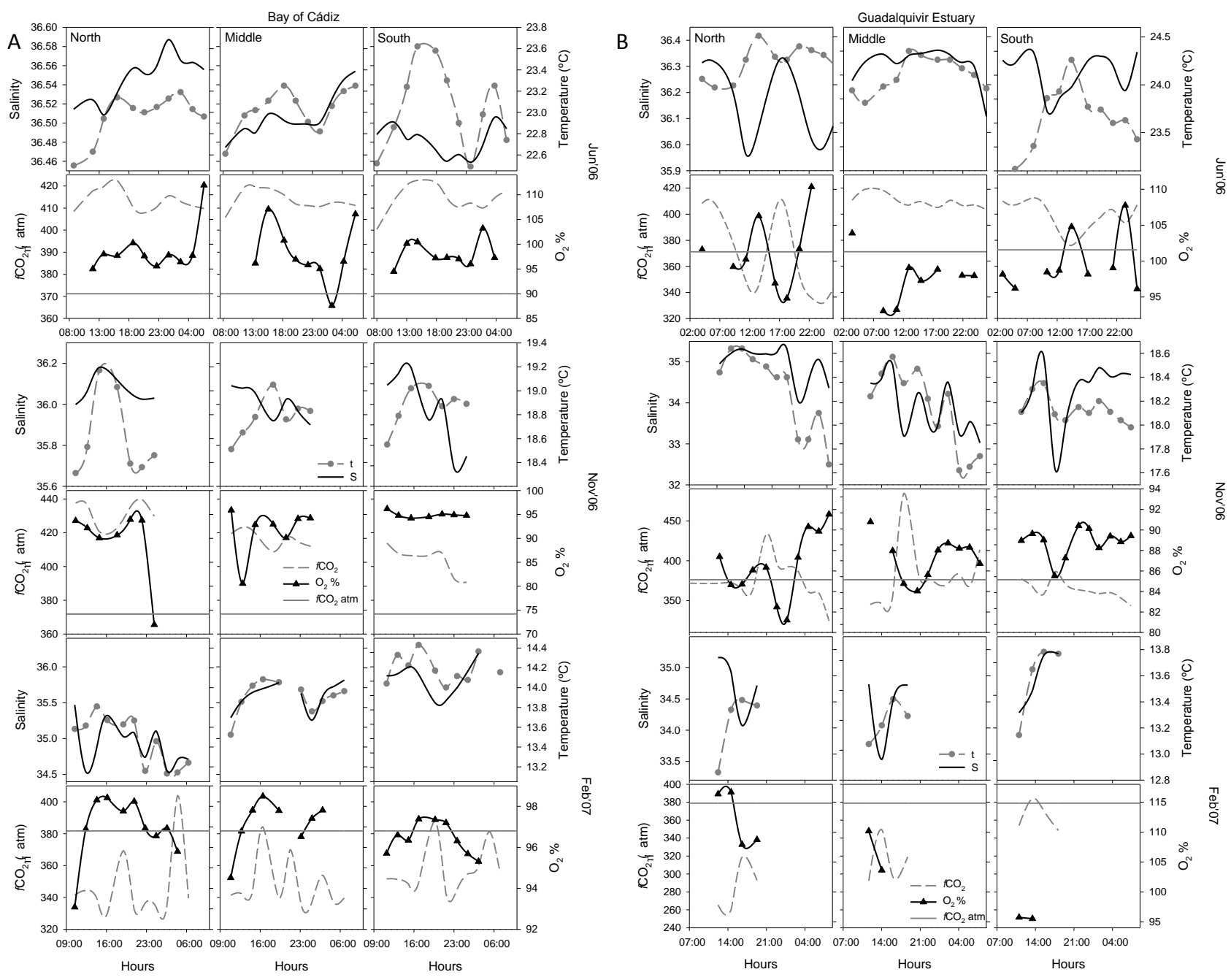

Fig. 3. Daily variations in surface seawater salinity (black solid line), temperature (grey dashed line with circle), $f \mathrm{CO}_{2}$ (grey dashed line) and percentage of oxygen saturation $\left(\% \mathrm{O}_{2}\right)$ (black solid line with triangles) from the transect off the Bay of Cádiz (A) and Guadalquivir estuary (B) at the three different stations (Fig. 1). Straight dark grey line is atmospheric $f \mathrm{CO}_{2}$.

the mean velocity was $4.85 \mathrm{~cm} \mathrm{~s}^{-1}$, while during ebb tide the velocity was $-5.67 \mathrm{~cm} \mathrm{~s}^{-1}$. However, we observed the north station of Guadalquivir had less tidal influence and more coastal current influence, with small onshore velocity during the three seasons. North of the Guadalquivir estuary, the predominant waves are from the west and the coast alienation is NW-SE, so the alongshore drift has no interruption until it arrives at the estuary (Contreras and Polo, 2010). Once there, the current stops and the sediment falls, forming the flecha de Doñana (Contreras and Polo, 2010). The Cádiz stations had mostly tidal influence without any remarkable current feature.

Diurnal evolution of salinity and temperature varied with tidal influence (Fig. 3). There were statistically significant differences between ebb and flood tide in salinity and temperature $(p<0.05, n=216)$. However, there were no statistically significant differences between ebb and flood tide for $f \mathrm{CO}_{2}$ and percentage of oxygen saturation $\left(\% \mathrm{O}_{2}\right)(p>$ $0.05, n=191)$. The processes controlling the $f \mathrm{CO}_{2}$ and $\%$ $\mathrm{O}_{2}$ dynamics are linked to various factors such as biological production/respiration, thermodynamic effects, mixing with adjacent waters, air-sea interchanges and day/night variations. Bozec et al. (2012) found the air-sea $\mathrm{CO}_{2}$ fluxes were influenced by these processes in the outer Loire estuary. Jiang et al. (2008) found significant difference in between hide tide and low tide sampling period in the Altamaha Sound, a riverdominated estuary. Litt et al. (2010) also found during some cruises that variability of $p \mathrm{CO}_{2}$ has tidal influence. They showed this relationship via a significant negative correlation with salinity and high temperature dependence.

Diurnal variability of $f \mathrm{CO}_{2}$ could have a potentially important implication on the estimate of air-sea $\mathrm{CO}_{2}$ fluxes. The Bay of Cádiz, during the whole tidal cycle sampling, behaved as a source (June and November) or as a sink 
Table 2. Fluxes of phosphate $\left(F_{\mathrm{PO} 4}\right)$, silicate $\left(F_{\mathrm{SiO} 2}\right)$, dissolved inorganic nitrogen $\left(F_{\mathrm{DIN}}\right)$, total dissolved nitrogen $\left(F_{\mathrm{TDN}}\right)$, dissolved organic carbon $\left(F_{\mathrm{DOC}}\right)$ and dissolved inorganic carbon $\left(F_{\mathrm{DIC}}\right)$ during the three sampling periods in the two different transects $($ Bay of Cádiz (BC) and Guadalquivir estuary (GL)). Extrapolate annual fluxes for every component. * means that the tidal cycle was not closed and the transport could be over-/underestimated.

\begin{tabular}{|c|c|c|c|c|c|c|c|c|c|c|c|c|}
\hline \multirow[b]{2}{*}{$\left(\mathrm{Mmol} \mathrm{d}^{-1}\right)$} & \multicolumn{2}{|c|}{$F_{\mathrm{PO} 4}$} & \multicolumn{2}{|c|}{$F_{\mathrm{SiO} 2}$} & \multicolumn{2}{|c|}{$F_{\text {DIN }}$} & \multicolumn{2}{|c|}{$F_{\mathrm{TDN}}$} & \multicolumn{2}{|c|}{$F_{\mathrm{DOC}}$} & \multicolumn{2}{|c|}{$F_{\text {DIC }}$} \\
\hline & $\mathrm{BC}$ & GL & $\mathrm{BC}$ & GL & $\mathrm{BC}$ & GL & $\mathrm{BC}$ & GL & $\mathrm{BC}$ & GL & $\mathrm{BC}$ & GL \\
\hline Jun 2006 & -0.0 & -0.1 & -0.6 & -0.2 & -0.2 & -0.6 & -5.5 & -3.3 & -83.4 & -61.6 & -955.7 & -1463.6 \\
\hline Nov 2006 & $0.8^{*}$ & -0.8 & $8.6^{*}$ & -16.0 & $9.9^{*}$ & -19.3 & $15.9 *$ & -33.4 & $280.1^{*}$ & -226.5 & $3747.6^{*}$ & -4055.2 \\
\hline Feb 2007 & 0.0 & $\mathrm{n}$ & 18.4 & $\mathrm{n}$ & 2.6 & $\mathrm{n}$ & 9.7 & $10.4^{*}$ & 72.0 & $29.9 *$ & 1827.7 & $555.2 *$ \\
\hline Annual Flux $\left(\mathrm{Gmol} \mathrm{yr}^{-1}\right)$ & 0.1 & -0.2 & 3.2 & -3.0 & 1.5 & -3.6 & 2.4 & -3.2 & 32.7 & -31.4 & 562.0 & -603.9 \\
\hline
\end{tabular}

$\mathrm{n}=$ not available.

(February) (Fig. 3a). In contrast, source/sink behaviour fluctuated in the same tidal cycle in the Guadalquivir estuary during June and November (Fig. 3b). This fact highlighted the dynamics of this coastal area and emphasized the importance of increasing the sampling frequency and/or the presence of mooring buoys with physicochemical sensors. On an annual scale, the global behaviour was a net source in agreement with Ribas-Ribas et al. (2011b), who reported flux in the more extended area of the same shelf. This result also agrees with Chen and Borges (2009), who distinguished between inner ecosystems as a source and continental shelf as a sink.

Tidal influence is not as evident for dissolved organic carbon (DOC), total dissolved nitrogen (TDN), dissolved inorganic carbon (DIC), $\mathrm{pH}$, nutrients (phosphate $\left(\mathrm{PO}_{4}\right)$, dissolved inorganic nitrogen (DIN) and silicate $\left.\left(\mathrm{SiO}_{2}\right)\right)$ and suspended particulate matter as for hydrographic parameters (Figs. 4 and 5). This fact could mainly be due to biological activity and daily (light/dark) variability. Ribas-Ribas et al. (2011b) reported that biological control over $f \mathrm{CO}_{2}$ was an important factor in this area. Guo et al. (2009) evaluate the tidal effect on carbon flux in the estuary of the Yangtze River. They similarly conclude that tides have substantial effects on carbon sequestration, although solar and temperature factors exert major controls on the carbon balance at temporal scales smaller than days.

The instantaneous fluxes of dissolved inorganic carbon $\left(F_{\text {DIC }}\right)$, at the four sampling positions in each transect for the three different sampling periods, reveal several important features in the diurnal flux data (Fig. 6). As was the case for current speed, positive $F$ values indicate onshore while negative values represent offshore flux. First, there was a marked tidal signal in the fluxes of all constituents at all stations except north of the Guadalquivir estuary, which normally have an offshore behaviour. Second, the fluxes were normally higher at the south station in the Guadalquivir estuary and at the north station in the Bay of Cádiz. Finally, in both transects, there was no significant difference between the surface and the depth sample (the middle station off the Guadalquivir estuary $(p=0.95, n=52)$ and in the south off the Bay of Cádiz $(p=0.91, n=58))$. A similar trend was evident with other constituent fluxes (plots and statistical test not shown).

\subsection{Seasonal influences on carbon and nutrient dynamics}

Both the Guadalquivir estuary and the Gulf of Cádiz acted as a source of $\mathrm{CO}_{2}$ to the atmosphere in early summer and autumn ( $f \mathrm{CO}_{2}$ above atmospheric value $\left(f \mathrm{CO}_{2}^{\text {atm }}\right.$ summer $=372 \mu \mathrm{atm}$ and $f \mathrm{CO}_{2}^{\text {atm }}$ autumn $\left.=373 \mu \mathrm{atm}\right)$ in Fig. 3) while as a sink of $\mathrm{CO}_{2}$ in winter $\left(f \mathrm{CO}_{2}\right.$ below atmospheric value $\left(f \mathrm{CO}_{2}^{\mathrm{atm}}\right.$ winter $\left.=380 \mu \mathrm{atm}\right)$ in Fig. 3$)$. When one considers carbon dynamics over coastal zones, it is promising to link the carbon behaviour of such a heterogeneous system (metabolic status with net ecosystem production (NEP)) with the lateral carbon transport with adjacent systems. Cai (2011) examined the net role of terrestrial loadings on ocean metabolism. He considers total organic carbon loading to the ocean as heterotrophic and dissolved inorganic nitrogen flux to the ocean as autotrophic loading. On a global scale, the impact of terrestrial loading on the ocean drives it to a more heterotrophic state (Cai, 2011). In the Guadalquivir estuary between June 2006 and February 2007, DOC loading exceeded DIN loading, driving the system to heterotrophy. This is in agreement with the annual NEP calculated in Ribas-Ribas et al. (2011a).

DOC and TDN have the highest concentration during November in the Guadalquivir estuary (Fig. 4). Plotting the absolute magnitude of instantaneous fluxes of a nonconservative variable (in this case [FTDN]) vs. those of salt (a predominantly conservative tracer) is a way to illustrate the landward vs. seaward dominance in the fluxes (Fig. 7). The response is not linear in either plot for all three seasons. The Bay of Cádiz plot showed a bell-shaped response with a minimum of $F(T D N)$ at Fsalt $=0$. These deviations could be greater during positive salt flux, which means that excess TDN is introduced into the system from local sources. In contrast, greater deviations during negative salt fluxes indicate that the system exports TDN to the adjacent coastal water. Bay of Cádiz has significant greater deviation from conservative behaviour during positive salt fluxes in November 

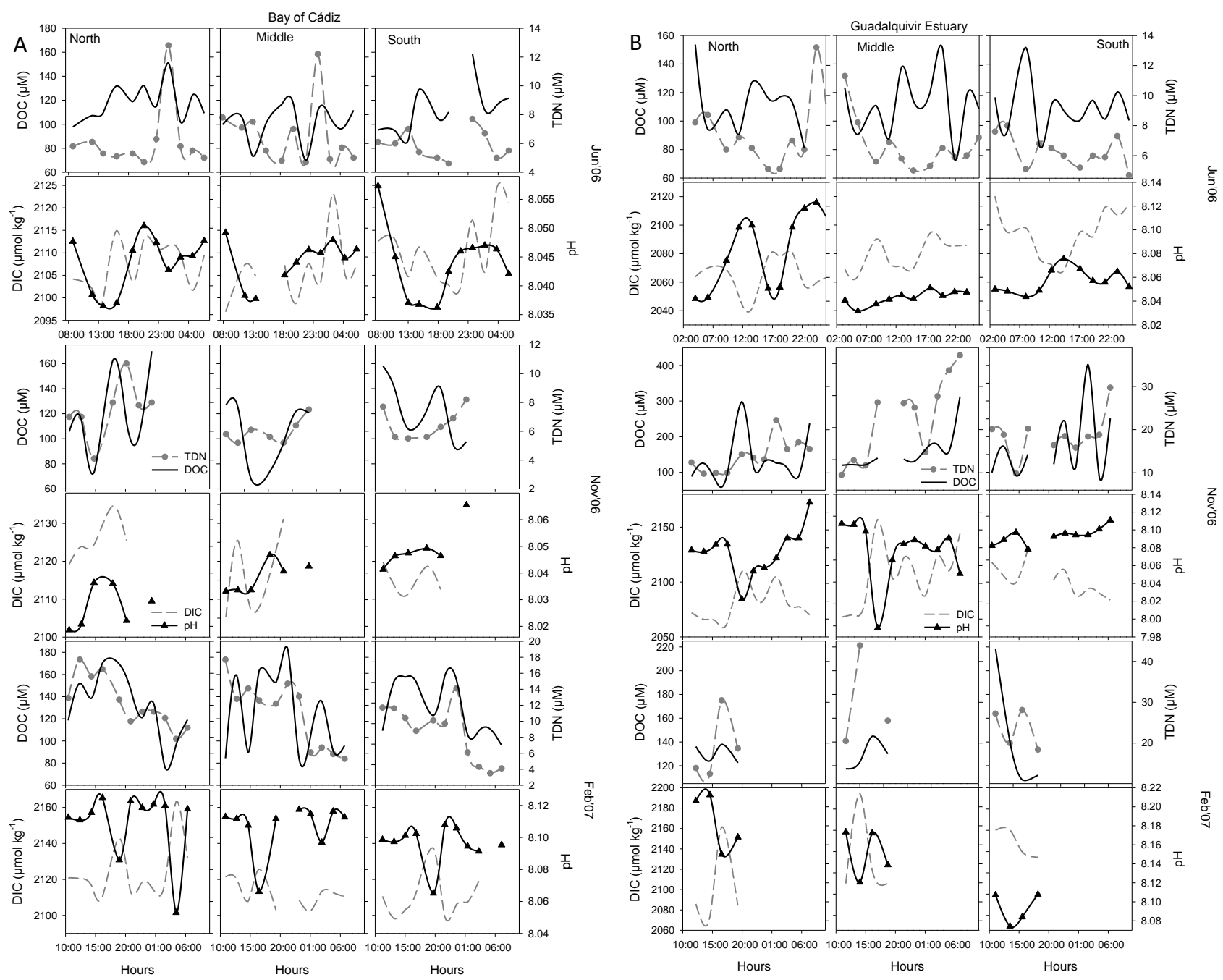

Fig. 4. Daily variations in surface seawater dissolved organic carbon (DOC) (black solid line), total dissolved nitrogen (TDN) (grey dashed line with circle), dissolved inorganic carbon (DIC) (grey dashed line) and $\mathrm{pH}$ (black solid line with triangles) from the transect off the Bay of Cádiz (A) and Guadalquivir estuary (B) at the three different stations (Fig. 1).

$(p=0.01, n=21)$. Seasonal differences also exist: for example, for the Bay of Cádiz, June TDN flux was significantly different than November TDN flux $(p=0.03, n=$ 87). For the Guadalquivir estuary, June TDN flux was significantly different from November and February TDN flux ( $p=0.0001, n=78$ ). Thus, during June both systems have seaward fluxes while in February both systems have landward fluxes (Fig. 7, Table 2). Landward fluxes have been observed in the Winyah Bay by Goñi et al. (2009).

The Guadalquivir estuary exported DIC in the early summer and autumn at a rate of $-1.5 \mathrm{Gmold}^{-1}$ and $-4.1 \mathrm{Gmol} \mathrm{d}^{-1}$, respectively (Fig. 6, Table 2 ). In winter, the estuary imported DIC at a rate of $0.5 \mathrm{Gmol} \mathrm{d}^{-1}$. This value was unexpected and possible due to the unfinished tidal cycle. Total carbon export $\left(F_{\mathrm{DIC}}, F_{\mathrm{DOC}}, F_{\mathrm{POC}}\right)$ from the estuary to the ocean during the study period amounted to $7 \mathrm{Tg}$ $\mathrm{C}$, of which $95 \%$ was in the inorganic form (DIC). Winter et al. (1996) reported that $83 \%$ of the total carbon export in the Swartkops estuary was in inorganic form. The Bay of Cádiz exhibited a different behaviour, acting as an import in the early summer and as an export during autumn and winter $\left(-1.0,3.7\right.$ and $1.8 \mathrm{Gmold}^{-1}$, respectively). The same behaviour was observed for the other constituents (Table 2). The Guadalquivir estuary has been identified as a net source of DIC, DOC, TDN and $f \mathrm{CO}_{2}$ (Ribas-Ribas et al., 2011a, b, c).

The Bay of Cádiz imported DIC from the continental shelf, with an annual value of $6740 \mathrm{Gg} \mathrm{C} \mathrm{yr}^{-1}$. De la Paz et al. (2008) calculated the DIC tidal export from Rio San Pedro (a tidal creek located within the Bay of Cádiz) to the bay. They identified the tidal pumping as the key mechanism of an annual average transport of $10 \mathrm{Gg} \mathrm{C} \mathrm{yr}^{-1}$. Forja et al. (2003) calculated a C export from the Sancti Petri Channel (an arm 

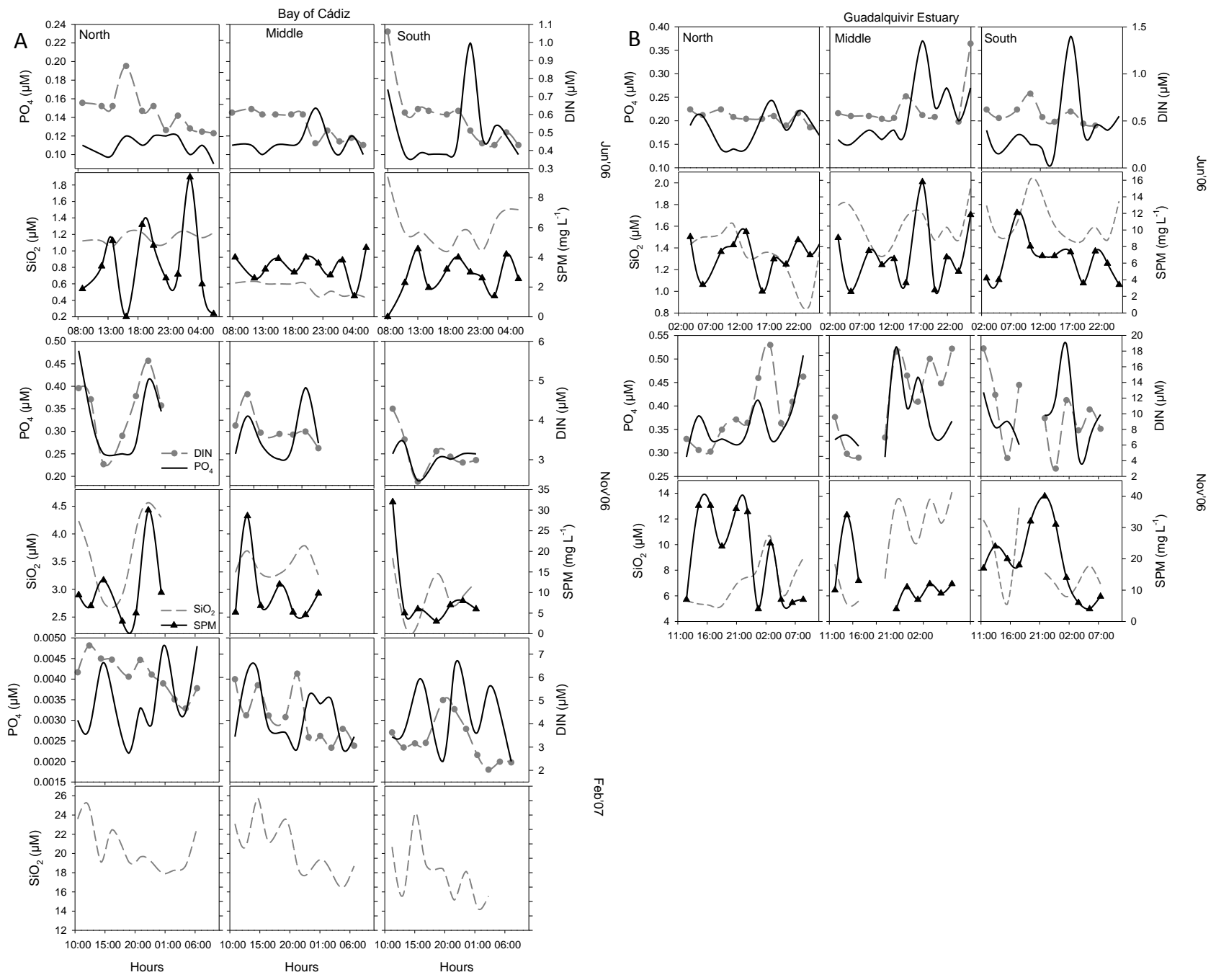

Fig. 5. Daily variations in surface seawater phosphate $\left(\mathrm{PO}_{4}\right)$ (black solid line), dissolved inorganic nitrogen (DIN) (grey dashed line with circle), silicate $\left(\mathrm{SiO}_{2}\right)$ (grey dashed line) and suspended particulate matter (black solid line with triangles) from the transect off the Bay of Cádiz (A) and Guadalquivir estuary (B) at the three different stations (Fig. 1).

of sea that connects the bay with the Atlantic) to the bay of $0.18 \mathrm{Gg} \mathrm{C} \mathrm{d}^{-1}$ during summer.

This transport was mainly driven by tidal influence and, in the case of the Guadalquivir estuary during autumn and winter, by river discharge. It should be pointed out that, due to incomplete tidal cycles, no different tidal phases (spring/neaps tides), and only three seasons measured, the annual fluxes should be taken with caution.

\subsection{Advantages and limits of current Earth observation technology for coastal biogeochemical studies}

From the measurements this study focuses on, the ones that have satellite algorithms are chlorophyll, primary production, SPM, photosynthetically active radiation and euphotic depth from ocean colour, salinity, currents from surface height and temperature.
Despite the geographic relevance of the Gulf of Cádiz for oceanographic research, only a few studies of ocean colour time series have been undertaken there with a goal of understanding better the phytoplankton blooms using remote sensing data (Navarro et al., 2012a; Sousa and Bricaud, 1992; Peliz and Fiúza, 1999; Navarro and Ruiz, 2006). Optical sensors, such as Moderate Resolution Imaging Spectroradiometer (MODIS), have improved freshwater monitoring capabilities and, in turn, the capacity to assist aquatic ecosystem managers (Navarro et al., 2012b).

However, the spatial and temporal resolutions of the composite images nowadays are not enough to assess the resolution of this study. Thus, the spatial and temporal resolutions of GlobColour composites are $4.6 \mathrm{~km}$ and 8 days respectively (Navarro et al., 2012a). The sea surface temperature data from the Advanced Very High Resolution Radiometer 


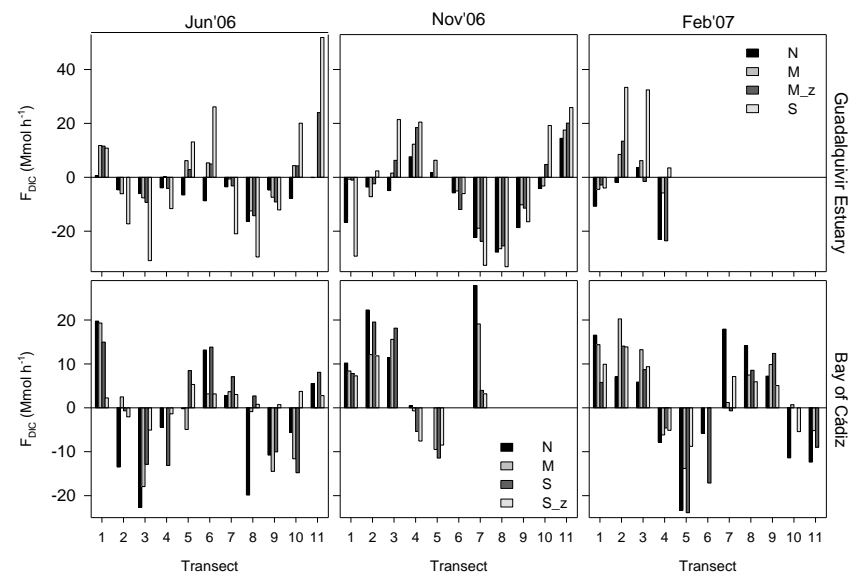

Fig. 6. Daily variations in dissolved inorganic carbon fluxes $\left(F_{\text {DIC }}\right)$ during June, November and February in the Guadalquivir estuary (upper panels) and the Bay of Cádiz (lower panels) at the different sampling stations.

(AVHRR) consist of 8-day composite at a spatial resolution of $4 \mathrm{~km}$ (Navarro et al., 2012a).

Sea surface salinity can be obtained from Aquarius and Soil Moisture and Ocean Salinity (SMOS) satellite. Aquarius provides better "pixel" accuracy than SMOS, whereas SMOS provides higher revisit times and spatial resolution. Aquarius has a 7-day revisit with a spatial resolution of $150 \mathrm{~km}$, which allows us to study seasonal and annual variations. SMOS observes ocean salinity for a 30-day average over an area of $200 \mathrm{~km}$.

Measurements of currents are fundamental to the oceanographic research and remain less well measured compared to other physical parameters (Ash et al., 2002). In the shelf seas the stringent requirements for spatial and temporal resolution mean that satellite systems are less suitable for monitoring the currents. Along-track interferometry both using synthetic aperture radar and using the radiometer, designed to measure sea surface temperature as a passive sensor for ocean current, can be used (Ash et al., 2002).

Therefore, seasonal and inter-annual cycles could be studied from satellite images. These techniques are also really helpful to identify extreme events like large phytoplankton bloom or rain periods. The obvious advantage of using satellite data is that you can look at synoptic scale features which are impossible to obtain with in situ data. The caveat in doing this is that you do not have validation for those products simultaneously in all locations.

Satellite imagery can resolve patterns on a large spatial scale but is confined to surface data (Navarro et al., 2012b). The difficulty in applying these techniques to our study is that we need hourly variation and less than $1 \mathrm{~km}$ spatial scales. Similar requirements are also necessary for offshore oil/gas operations, fishing, search and rescue and leisure industries (Ash et al., 2002).

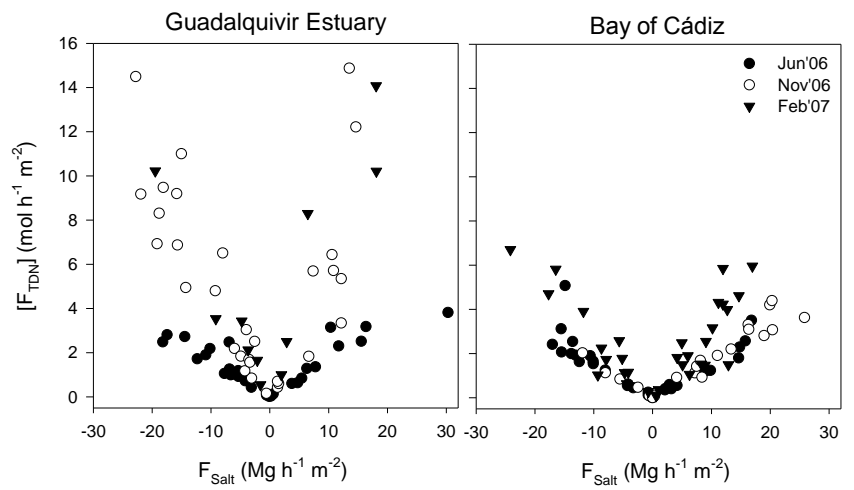

Fig. 7. Instantaneous salinity fluxes $\left(F_{\text {Salt }}\right)$ versus the absolute magnitude of instantaneous total dissolved nitrogen fluxes ( $\left.\left[F_{\mathrm{TDN}}\right]\right) \mathrm{de}-$ termined in the two study areas (Guadalquivir estuary and the Bay of Cádiz) in the three different sampling periods: June 2006 (black circles), November 2006 (white circles) and February 2007 (black triangles).

\section{Conclusions}

The Bay of Cádiz imported $0.1 \mathrm{Gmol}$ of $\mathrm{PO}_{4}, 3.2 \mathrm{Gmol}$ of $\mathrm{SiO}_{2}, 1.5 \mathrm{Gmol}$ of DIN, $2.4 \mathrm{Gmol}$ of TDN, $32.7 \mathrm{Gmol}$ of DOC and $562.0 \mathrm{Gmol}$ of DIC, on an annual scale, while the Guadalquivir estuary exported $0.2,3.2,1.5,3.2,31.4$, and $603.9 \mathrm{Gmol}$ of $\mathrm{PO}_{4}, \mathrm{SiO}_{2}$, DIN, TDN, DOC and DIC respectively to the adjacent coastal area. During June, both systems exported components to the adjacent continental shelf of the Gulf of Cádiz. Daily variability between $\mathrm{CO}_{2}$ source/sink behaviour has been observed in the Guadalquivir estuary in June and November. These highlight coastal zones as highly dynamic areas, and further studies are needed to better understand these systems.

A high-resolution geo-stationary mission at $1 \mathrm{~km}$ resolution and hourly coverage is needed to address this important type of study with satellite data.

Acknowledgements. The authors thank the crew of the R/V Mytilus for their valuable assistance during the cruises. This work was supported by the Spanish CICYT (Spanish Program for Science and Technology) under contracts CTM 2008-04807, CTM2011-27891 and PO7-RNM-03197. M. Ribas-Ribas and E. Anfuso were funded by the Spanish Ministry of Education with doctoral fellowships. We thank Lidia Carracedo for the ADCP data treatment and Tim Smyth for Earth observation advice. M. Ribas-Ribas had EGU travel financial support to assist in the Earth observation for Ocean-Atmosphere Interactions Science; ESA, SOLAS, EGU joint Conference. We thank the two anonymous reviewers, the editor and Pierre Polsenaere for their helpful discussions and comments, which have greatly improved the original manuscript.

Edited by: D. Fernández Prieto 


\section{References}

Ash, E., Baynes, P., Dumper, K., Gommenginger, C., Gleason, S., and Mutlow, C.: Ocean Currents from space. Document No.: SOS-OC-REP-4/01. BNSC Service Mission Support (SMS) Programme, Report for WP4: Systems vs. requirements, product delivery approach and outline business plan., 28 pp., 2002.

Borges, A. V. and Frankignoulle, M.: Distribution and air-water exchange of carbon dioxide in the Scheldt plume off the Belgian coast, Biogeochemistry, 59, 41-67, 2002.

Bozec, Y., Cariou, T., Macé, E., Morin, P., Thuillier, D., and Vernet, M.: Seasonal dynamics of air-sea $\mathrm{CO}_{2}$ fluxes in the inner and outer Loire estuary (NW Europe), Estuar. Coast. Shelf S., 100, 58-71, doi:10.1016/j.ecss.2011.05.015, 2012.

Cai, W.-J.: Estuarine and coastal ocean carbon paradox: $\mathrm{CO}_{2}$ sinks or sites of terrestrial carbon incineration?, Annu. Rev. Marine Sci., 3, 123-145, doi:10.1146/annurev-marine-120709-142723, 2011.

Chen, C.-T. A. and Borges, A. V.: Reconciling opposing views on carbon cycling in the coastal ocean: Continental shelves as sinks and near-shore ecosystems as sources of atmospheric $\mathrm{CO}_{2}$, Deep-Sea Res. Pt. II, 56, 578-590, 2009.

Contreras, E. and Polo, M.: Propuesta metodológica para diagnosticar y pronosticar las consecuencias de las actuaciones humanas en el estuario del Guadalquivir, technical report, Group of Fluvial Dyn. and Hydrol., University of Córdoba, Córdoba, Spain, 2010.

Dale, A. W. and Prego, R.: Tidal and seasonal nutrient dynamics and budget of the Chupa Estuary, White Sea (Russia), Estuar. Coast. Shelf S., 56, 377-389, 2003.

de la Paz, M., Gómez-Parra, A., and Forja, J. M.: Inorganic carbon dynamic and air-water $\mathrm{CO}_{2}$ exchange in the Guadalquivir Estuary (SW Iberian Peninsula), J. Marine Syst., 68, 265-277, 2007.

de la Paz, M., Gómez-Parra, A., and Forja, J.: Tidal-to-seasonal variability in the parameters of the carbonate system in a shallow tidal creek influenced by anthropogenic inputs, Rio San Pedro (SW Iberian Peninsula), Cont. Shelf Res., 28, 1394-1404, 2008.

DelValls, T. and Dickson, A.: The pH of buffers based on 2-amino2-hydroxymethyl-1, 3-propanediol ("tris") in synthetic sea water, Deep-Sea Res. Pt. I, 45, 1541-1554, 1998.

Dickson, A. G.: Standard potential of the reaction $\mathrm{AgCl}(\mathrm{s})+1 / 2 \mathrm{H}_{2}$ $(\mathrm{g})=\mathrm{Ag}(\mathrm{s})+\mathrm{HCl}(\mathrm{aq})$ and the standard acidifty constant of the bisulfate ion in synthetic seawater from $273.15 \mathrm{~K}$ to $318.15 \mathrm{~K}$, J. Chem. Thermodyn., 22, 113-127, doi:10.1016/00219614(90)90074-z, 1990.

Dickson, A. G. and Millero, F. J.: A comparison of the equilibrium constants for the dissociation of carbonic acid in seawater media, Deep-Sea Res., 34, 1733-1743, doi:10.1016/01980149(87)90021-5, 1987.

Dickson, A. G. and Riley, J. P.: The effect of analytical error on the evaluation of the components of the aquatic carbon-dioxide system, Mar. Chem., 6, 77-85, 1978.

Dickson, A. G., Sabine, C. L., and Christian, J. R.: Guide to best practices for ocean $\mathrm{CO}_{2}$ measurements, PICES Special Publication, 3, 2007.

Forja, J. M., Ortega, T., Ponce, R., de la Paz, M., Rubio, J. A., and Gómez-Parra, A.: Tidal transport of inorganic carbon and nutrients in a coastal salt marsh (Bay of Cádiz, SW Spain), Cienc. Mar., 29, 469-481, 2003.
Goñi, M. A., Voulgaris, G., and Kim, Y. H.: Composition and fluxes of particulate organic matter in a temperate estuary (Winyah Bay, South Carolina, USA) under contrasting physical forcings, Estuar. Coast. Shelf S., 85, 273-291, 2009.

Gordon, D. C., Boudreau, P., Mann, K., Ong, J., Silvert, W., Smith, S., Wattayakorn, G., Wulff, F., and Yanagi, T.: LOICZ biogeochemical modelling guidelines, LOICZ Core Project, Netherlands Institute for Sea Research, 1996.

Grasshoff, K., Ehrhardt, M., and Kremling, K.: Methods of seawater analysis, Verlag Chemie, Weinheim, Germany, 419 pp., 1983.

Guo, H., Noormets, A., Zhao, B., Chen, J., Sun, G., Gu, Y., Li, B., and Chen, J.: Tidal effects on net ecosystem exchange of carbon in an estuarine wetland, Agr. Forest Meteorol., 149, 1820-1828, 2009.

Huertas, I. E., Navarro, G., Rodríguez-Gálvez, S., and Lubián, L. M.: Temporal patterns of carbon dioxide in relation to hydrological conditions and primary production in the northeastern shelf of the Gulf of Cadiz (SW Spain), Deep-Sea Res Pt. II, 53, 13441362, 2006.

Jiang, L.-Q., Cai, W.-J., and Wang, Y.: A comparative study of carbon dioxide degassing in river-and marinedominated estuaries, Limnol. Oceanogr., 53, 2603-2615, doi:10.4319/lo.2008.53.6.2603, 2008.

Lebot, P., Kermabon, C., Lherminier, P., and Gaillard, F.: CASCADE V6.1: Logiciel de validation et de visualisation des mesures ADCP de coque, IFREMER, Centre de Brest, France, 2011.

Litt, E. J., Hardman-Mountford, N. J., Blackford, J. C., MitchelsonJacob, G., Goodman, A., Moore, G. F., Cummings, D. G., and Butenschön, M.: Biological control of $p \mathrm{CO}_{2}$ at station L4 in the Western English Channel over 3 years, J. Plankton Res., 32, 621629, 2010.

Loring, D. and Rantala, R.: Manual for the geochemical analyses of marine sediments and suspended particulate matter, Earth-Sci. Rev., 32, 235-283, 1992.

Mehrbach, C., Culberso, C. H., Hawley, J. E., and Pytkowic, R. M.: Measurement of apparent dissociation constants of carbonic acid in seawater at atmospheric pressure, Limnol. Oceanogr., 18, 897907, 1973.

Navarro, G., and Ruiz, J.: Spatial and temporal variability of phytoplankton in the Gulf of Cádiz through remote sensing images, Deep-Sea Res Pt. II, 53, 1241-1260, 2006.

Navarro, G., Caballero, I., Prieto, L., Vázquez, A., Flecha, S., Huertas, I. E., and Ruiz, J.: Seasonal-to-interannual variability of chlorophyll- $a$ bloom timing associated with physical forcing in the Gulf of Cádiz, Adv. Space Res., 50, 1164-1172, 2012a.

Navarro, G., Huertas, I. E., Costas, E., Flecha, S., Díez-Minguito, M., Caballero, I., López-Rodas, V., Prieto, L., and Ruiz, J.: Use of a real-time remote monitoring network (RTRM) to characterize the Guadalquivir estuary (Spain), Sensors, 12, 1398-1421, 2012 b.

Peliz, A. and Fiúza, A.: Temporal and spatial variability of CZCSderived phytoplankton pigment concentrations off the western Iberian Peninsula, Int. J. Remote Sens., 20, 1363-1403, 1999.

Ribas-Ribas, M., Gómez-Parra, A., and Forja, J. M.: Seasonal distribution of the inorganic carbon system and net ecosystem production in the north eastern shelf of the Gulf of Cádiz (Southwest Iberian Peninsula), Cont. Shelf Res., 31, 1931-1942, 2011a. 
Ribas-Ribas, M., Gómez-Parra, A., and Forja, J. M.: Air-sea $\mathrm{CO}_{2}$ fluxes in the north-eastern shelf of the Gulf of Cádiz (southwest Iberian Peninsula), Mar. Chem., 123, 56-66, 2011 b.

Ribas-Ribas, M., Gómez-Parra, A., and Forja, J. M.: Spatiotemporal variability of the dissolved organic carbon and nitrogen in a coastal area affected by river input: The north eastern shelf of the Gulf of Cádiz (SW Iberian Peninsula), Mar. Chem., 126, 295-308, 2011c.

Ribas-Ribas, M., Sobrino, C., Debelius, B., Lubián, L. M., Ponce, R., Gómez-Parra, A., and Forja, J. M.: Picophytoplankton and carbon cycle on the northeastern shelf of the Gulf of Cádiz (SW Iberian Peninsula), Sci. Mar., 77, 49-62, 2013.

Sousa, F. M. and Bricaud, A.: Satellite-derived phytoplankton pigment structures in the Portuguese upwelling area, J. Geophys. Res. (C Oceans), 97, 11343-11356, 1992.
Takahashi, T., Olafsson, J., Goddard, J. G., Chipman, D. W., and Sutherland, S. C.: Seasonal variation of $\mathrm{CO}_{2}$ and nutrients in the high-latitutde surface oceans - A comparative study, Global Biogeochem. Cy., 7, 843-878, doi:10.1029/93gb02263, 1993.

Vargas, J., Garcia-Lafuente, J., Delgado, J., and Criado, F.: Seasonal and wind-induced variability of sea surface temperature patterns in the Gulf of Cádiz, J. Marine Syst., 38, 205-219, 2003.

Walsh, J. J.: Importance of continental margins in the marine biogeochemical cycling of carbon and nitrogen, Nature, 350, 123132, 1991.

Winter, P. E., Schlacherl, T. A., and Baird, D.: Carbon flux between an estuary and the ocean: a case for outwelling, Hydrobiologia, 337, 123-132, 1996. 